\title{
Pituitary adenylate cyclase-activating polypeptide stimulates corticotropin-releasing factor, vasopressin and interleukin-6 gene transcription in hypothalamic $4 B$ cells
}

\author{
Kazunori Kageyama, Komaki Hanada, Yasumasa Iwasaki ${ }^{1}$, Satoru Sakihara, Takeshi Nigawara, \\ John Kasckow ${ }^{2}$ and Toshihiro Suda \\ Department of Endocrinology and Metabolism, Hirosaki University Graduate School of Medicine, 5 Zaifu-cho, Hirosaki, Aomori 036-8562, Japan \\ ${ }^{1}$ Department of Endocrinology, Metabolism and Nephrology, Kochi Medical School, Kochi University, Oko-cho, Kohasu, Nankoku 783-8505, Japan \\ ${ }^{2}$ Department of Psychiatry, University of Cincinnati School of Medicine, 231 Bethesda Avenue (ML 559), Cincinnati, Ohio 45267, USA \\ (Correspondence should be addressed to K Kageyama; Email: kkageyama@hkg.odn.ne.jp)
}

\begin{abstract}
Corticotropin-releasing factor (CRF) and arginine vasopressin (AVP) are the two major regulatory peptides in the hypothalamic-pituitary-adrenal axis. CRF, produced in the hypothalamic paraventricular nucleus (PVN) in response to stress, is secreted into the pituitary portal circulation, resulting in the release of adrenocorticotropic hormone from the anterior pituitary. AVP is synthesized in the PVN and supraoptic nucleus by various stressors. Hypothalamic $4 \mathrm{~B}$ cells coexpress CRF and AVP. In 4B cells transfected with either a CRF or an AVP promoter-luciferase construct, forskolin increased the transcriptional activity of CRF or AVP. In the present study, we tried to determine whether pituitary adenylate cyclase-activating polypeptide (PACAP) regulates both CRF and AVP genes in the hypothalamic cells, because receptors for PACAP were expressed in the hypothalamic
\end{abstract}

cells. PACAP stimulated activity of both CRF and AVP promoter via protein kinase A pathway. PACAP stimulated interleukin (IL)-6 promoter activity and the levels of IL-6 mRNA and protein. IL-6 stimulated activity of both CRF and AVP promoter in a dose-dependent manner. Finally, we found that the stimulatory effects of PACAP on both activities were significantly inhibited by treatment with anti-IL-6 monoclonal antibody. These data suggest that PACAP is involved in regulating the synthesis of IL-6 mRNA and IL-6 protein, and that the increase in endogenous IL-6 also contributes to stimulate the expression of both CRF and AVP genes. Taken together, these findings indicate that PACAP stimulates the transcription of CRF, AVP, and IL-6 genes in hypothalamic 4B cells.

Journal of Endocrinology (2007) 195, 199-211

\section{Introduction}

Corticotropin-releasing factor (CRF) and arginine vasopressin (AVP) are the two major regulatory peptides in the hypothalamic-pituitary-adrenal (HPA) axis. CRF, produced in the hypothalamic paraventricular nucleus (PVN) in response to stress (Whitnall 1993), is secreted into the pituitary portal circulation, resulting in the release of adrenocorticotropic hormone (ACTH) via the CRF receptor type $1\left(\mathrm{CRF}_{1}\right.$ receptor) from the anterior pituitary (AP). ACTH then stimulates glucocorticoid release from the adrenal glands (Whitnall 1993). Glucocorticoid in turn inhibits hypothalamic PVN production of CRF and pituitary production of ACTH. We previously demonstrated that the protein kinase A (PKA) pathway plays a major role in releasing CRF in hypothalamic tissues (Suda et al. 1985). Other studies also support the hypothesis that stimulation of the PKA pathway in CRF neurons increases CRF expression, and indicate that cyclic AMP (cAMP)-dependent signaling activates CRF gene expression (Seasholtz et al. 1988, Spengler et al. 1992). A functional cAMP-response element (CRE) in the $5^{\prime}$-promoter region of CRF gene takes a part in regulating its gene expression (Seasholtz et al. 1988, Spengler et al. 1992).

AVP is synthesized in both magnocellular and parvocellular regions of the PVN, and in the supraoptic nucleus (SON). Expression of the AVP gene in the SON and PVN is regulated by inflammation, cytokines, and an acute stress (Burbach et al. 2001). Magnocellular AVP neurons in the PVN and SON project to the neural lobe of the pituitary, whereas AVP neurons in the parvocellular region of the PVN project to the external zone of the median eminence (ME) to stimulate ACTH production in the corticotrophs (Vandesande et al. 1977).

Pituitary adenylate cyclase-activating polypeptide (PACAP), a member of the secretin/glucagon/vasoactive intestinal peptide (VIP) family, is found in two forms in the 
mammalian central nervous system (CN): a 38 amino acid peptide (PACAP38) and an N-terminally truncated 27 amino acid peptide (PACAP27; Miyata et al. 1989, 1990). PACAP acts by binding to PACAP receptor 1 (PAC1 receptor) and two VIP-preferring receptors (VPAC1 and VPAC2 receptors). These receptors have different affinities for PACAP and VIP (Harmar et al. 1998). PACAP and the PACAP-selective PAC1 receptors are known to be highly expressed in the hypothalamus, including the parvocellular and magnocellular subdivisions of the PVN, and the SON (Nomura et al. 1996, Shioda et al. 1997a).

PACAP has shown to stimulate cAMP production in the AP (Miyata et al. 1989). PACAP also increases CRF mRNA levels in the parvocellular region of the PVN, suggesting that PACAP is involved in the positive regulation of CRF gene expression (Grinevich et al. 1997). Therefore, it is suggested that PACAP might regulate the HPA axis by stimulation of CRF gene expression in the hypothalamus and through direct effects on pituitary corticotrophs (Boutillier et al. 1994, Aoki et al. 1997, Agarwal et al. 2005). PACAP also activates AVP neurons of the PVN or SON via PAC1 receptor (Shioda et al. 1997b, Nomura et al. 1999).

Interleukin (IL)-6 also shows a variety of biological activities. Plasma IL-6 levels rise in response to both immune activation and non-immune stress (Zhou et al. 1993, Takaki et al. 1994). IL-6 prompts lymphocytic proliferation and differentiation (Schimpl \& Wecker. 1972) and induces production of acute-phase proteins in the liver (Castell et al. 1989). In addition, IL-6 stimulates the HPA axis (Venihaki et al. 2001), increasing glucocorticoid levels, which in turn suppress IL-6 production (Karalis et al. 1997, Turnbull \& Rivier 1999). Therefore, IL-6 is an important mediator of the interaction between the neuroendocrine and immune systems. IL-6 also plays a role in the regulation of CRF and AVP. For example, IL-6 increases CRF gene expression and secretion in the hypothalamus (Navarra et al. 1991, Vallieres \& Rivest 1999). IL-6 is coexpressed with AVP in the SON and PVN neurons (Ghorbel et al. 2003) and also induces AVP secretion in the hypothalamus (Mastorakos et al. 1994).

Little is known about the signaling pathways involved in the control of CRF and AVP transcription in parvocellular PVN neurons due to the lack of availability of homologous hypothalamic cells (Kasckow et al. 2003a). A fetal rat hypothalamic $4 \mathrm{~B}$ cell line shows characteristics of the parvocellular neurons of the PVN (Kasckow et al. 2003b) and expresses CRF, AVP, and $\mathrm{CRF}_{1}$ and glucocorticoid receptors. In the cells transfected with either a CRF or AVP promoterluciferase construct, forskolin increased CRF or AVP transcriptional activity in parallel with increases in intracellular cAMP (Nikodemova et al. 2003). In the present study, we asked whether PACAP is involved in the responses of CRF and AVP promoter activities in the hypothalamic $4 \mathrm{~B}$ cells. We further explored the involvement of PACAP in the regulation of IL-6 gene expression in the hypothalamic cells.

\section{Materials and Methods}

\section{Materials}

Forskolin was purchased from Calbiochem (San Diego, CA, USA). PACAP38 was purchased from the Peptide Institute (Osaka, Japan). H89 was purchased from Seikagaku Corporation (Tokyo, Japan). PD98059 and SQ22536 were purchased from Cabiochem. Rat IL-6 was purchased from PeproTech (London, UK). Anti-rat IL-6 MAB was purchased from Biosource (Camarillo, CA, USA).

\section{Animals}

Adult male Wistar rats (body weight, BW 280-320 g) were housed in a temperature-controlled room with controlled lighting (light 0600-1800 h) and were given free access to laboratory chow and tap water. The rats were decapitated for tissue collection (hypothalamic tissue and anterior pituitary). This study was carried out in accordance with the Guidelines for Animal Experimentation, Hirosaki University.

\section{Cell culture}

Rat hypothalamic 4B cells were incubated in Dulbecco's modified eagle's medium (DMEM) supplemented with 10\% fetal bovine serum (FBS), $100 \mu \mathrm{g} / \mathrm{ml}$ streptomycin, and $100 \mathrm{U} / \mathrm{ml}$ penicillin at $37^{\circ} \mathrm{C}$ in a humidified atmosphere of $5 \%$ $\mathrm{CO}_{2}$ and $95 \%$ air. Cells were plated at $10^{4}$ cells $/ \mathrm{cm}^{2} 4$ days before each experiment, with the medium being changed for every $48 \mathrm{~h}$. On day 3, cells were washed and starved overnight with DMEM supplemented with $0 \cdot 2 \%$ BSA. On day 4 , cells were incubated in medium with added vehicle, forskolin, with or without medium containing one of various inhibitors or an antagonist.

\section{Constructs and transfection}

A 1077 bp restriction fragment containing the CRF promoter $(-907$ to +170 relative to the proximal transcription start point) and an $829 \mathrm{bp}$ restriction fragment containing the AVP promoter $(-803$ to +26$)$ were obtained by PCR. The PCR products were then confirmed by sequences. The DNA fragments were used to produce the CRF and AVP promoterdriven luciferase reporter constructs, CRF-907luc and AVP-803luc respectively by a two-step cloning method. First, the DNA fragment was cloned into pGEM-T Easy vector (Promega Corp.), then digested with Kpn I and Hind III, and subcloned into Kpn I and Hind III cloning sites of the pA3-Luc plasmid. A 543 bp restriction fragment containing the IL-6 promoter $(-522$ to +21$)$ was obtained from rat genomic DNA. This DNA fragment was used to produce the IL-6 promoter-driven luciferase reporter construct, IL-6luc, by the two-step cloning method.

For the luciferase activity assay, cells were placed in 12-well (22 $\mathrm{mm}$ diameter) culture trays at $60 \%$ confluency. The next day, cells were transfected following the manufacturer's instructions using the FuGENE 6 Transfection Reagent Kit 
(Roche Diagnostics). FuGENE $3 \mu \mathrm{l} / 1 \mu \mathrm{g}$ DNA was used. For each well, the total amount of DNA was $0.5 \mu \mathrm{g}$. The culture medium was then replaced with DMEM supplemented with 10\% FBS. One day before each experiment, cells were washed and starved overnight in DMEM supplemented with $0 \cdot 2 \%$ BSA.

\section{Luciferase activity}

The luciferase assay was performed according to the manufacturer's protocol. At the end of each experiment, cells were washed twice with PBS without $\mathrm{Ca}^{2+}$ and $\mathrm{Mg}^{2+}$, harvested with PicaGene lysis buffer (Toyo Inki, Tokyo, Japan), and centrifuged at 12000 r.p.m. for $2 \mathrm{~min}$. For the luciferase assay, $20 \mu \mathrm{l}$ of each supernatant was used. The reactions were started by the injection of $100 \mu \mathrm{l}$ luciferin solution, PicaGene buffer. Light output was measured for $20 \mathrm{~s}$ at room temperature using a luminometer (Berthold Lumat LB9501, Postfach, Germany). Activity of $\beta$-galactosidase was used as an internal control. Cells were treated in triplicate in each experiment, with the average of three independent experiments shown in figures.

\section{cAMP assay}

Serum-starved 4B cells were pre-incubated for $20 \mathrm{~min}$ with $0.1 \mathrm{mM}$ of 3 -isobutyl-1-methylxanthine in assay medium and then treated at $37^{\circ} \mathrm{C}$ for $20 \mathrm{~min}$ with the indicated concentrations of each peptide. The medium was aspirated and cells extracted with $1 \mathrm{ml}$ of $95 \%$ ethanol containing $0 \cdot 1 \mathrm{M}$ $\mathrm{HCl}$. cAMP content was measured in the supernatants using commercial cAMP EIA kits (Amersham Pharmacia Biotech). Cells were treated in triplicate in each experiment, with the average of three independent experiments shown in figures.

\section{$R N A$ extraction}

Cellular total RNA was extracted using the RNeasy Mini Kit (Qiagen) according to the manufacturer's protocol. Then, cDNAs were synthesized from total RNA $(0.5 \mu \mathrm{g})$ using random hexamers as primers with the SuperScript FirstStrand Synthesis System for reverse transcriptase-PCR (RT-PCR) Kit (Invitrogen Corp.) according to the manufacturer's instructions.

\section{Reverse transcriptase-PCR (RT-PCR)}

PCR was carried out in a programmable thermal controller (Bio-Rad) with the following oligonucleotide primers: CRF-F (5'-TGGATCTCACCTTCCACCTTCTG-3'), CRF-R (5'-CCGATAATCTCCATCAGTTTCCTG-3'); AVP-F (5'-ACATCCGACATGGAGCTG-3'), AVP-R (5'-GCGGAAAAAACCCTCTCG-3') (Nagano et al. 1997); $\beta 2-M i c r o-$ globulin (B2MG)-F (5'-CGGTGACCG- TGATCTTT- CT GGT-3 $\left.{ }^{\prime}\right)$, B2MG-R (5'-GGTGACGGTTTTGGGCTC$\mathrm{CTT}^{\prime} 3^{\prime}$ ) (Neumann et al. 1997); PAC1 receptor-F (5'-TTTCATCGGCATCATCATCATCCTT- $\left.3^{\prime}\right)$, PAC1 receptor-R $\left(5^{\prime}\right.$-CCTTCCAGCTCCTCCATTTCCTCTT-3 $\left.{ }^{\prime}\right)$ (Ajpru et al. 2002); VPAC1 receptor-F (5'-TGATTGAGATACAGCGTCAG-3 ${ }^{\prime}$ ), VPAC1 receptor-R (5'-CCTCAGAGCAGTGGTCTATC-3') (Chaudhary \& Baumann 2002); VPAC2 receptor-F (5'-TTGGGCTACAGTGTTTCTCT-3'), VPAC2 receptor-R (5'-ATTAGCAGCAGTGTGGACTT- $\left.3^{\prime}\right)$. Conditions for the CRF were $1 \times$ $\left(95^{\circ} \mathrm{C}, 3 \mathrm{~min}\right), 40 \times\left(95^{\circ} \mathrm{C}, 20 \mathrm{~s} ; 62^{\circ} \mathrm{C}, 30 \mathrm{~s} ; 72{ }^{\circ} \mathrm{C}, 30 \mathrm{~s}\right)$ and $1 \times\left(95^{\circ} \mathrm{C}, 1 \mathrm{~min} ; 55^{\circ} \mathrm{C}, 1 \mathrm{~min}\right)$. Conditions for the AVP were $45 \times\left(94^{\circ} \mathrm{C}, 1 \mathrm{~min} ; 54^{\circ} \mathrm{C}, 1 \mathrm{~min} ; 72{ }^{\circ} \mathrm{C}, 2 \mathrm{~min}\right)$. Conditions for the $\mathrm{B} 2 \mathrm{MG}$ were $1 \times\left(95^{\circ} \mathrm{C}, 3 \mathrm{~min}\right), 48 \times\left(93{ }^{\circ} \mathrm{C}, 1 \mathrm{~min}\right.$; $\left.65^{\circ} \mathrm{C}, 1 \mathrm{~min} ; 72^{\circ} \mathrm{C}, 1 \mathrm{~min}\right)$ and $1 \times\left(72{ }^{\circ} \mathrm{C}, 5 \mathrm{~min}\right)$. Conditions for the PAC1 receptor were $1 \times\left(94^{\circ} \mathrm{C}, 2 \mathrm{~min}\right)$, $40 \times\left(94{ }^{\circ} \mathrm{C}, 1 \mathrm{~min} ; 58^{\circ} \mathrm{C}, 1 \mathrm{~min} ; 72^{\circ} \mathrm{C}, 2 \mathrm{~min}\right)$ and $1 \times$ $\left(75^{\circ} \mathrm{C}, 5 \mathrm{~min}\right)$. Conditions for the VPAC1 and VPAC2 receptors were $1 \times\left(94{ }^{\circ} \mathrm{C}, 5 \mathrm{~min}\right), 35 \times\left(94^{\circ} \mathrm{C}, 30 \mathrm{~s} ; 55^{\circ} \mathrm{C}\right.$, $\left.40 \mathrm{~s} ; 72^{\circ} \mathrm{C}, 70 \mathrm{~s}\right)$, and $1 \times\left(72^{\circ} \mathrm{C}, 7 \mathrm{~min}\right)$. Products were separated by electrophoresis on a 1.2 or $4 \%$ (for CRF) agarose gel containing ethidium bromide, followed by quantitative analysis using the NIH image software 1.61 (Bethesda, MD, USA. The results are expressed as corrected arbitrary units. The expected sizes of PCR products for CRF and AVP were 101 and 270 bp respectively. The expected size of PCR products for B2MG was $332 \mathrm{bp}$. The expected sizes of PCR products for PAC1 receptor were 374 bp (a variant with a single 84 bp insert) and $290 \mathrm{bp}$ (short isoform). The expected sizes of PCR products for VPAC1 and VPAC2 receptors were 509 and 607 bp respectively.

\section{Real-time RT-PCR}

Resulting cDNAs were subjected to real-time PCR as follows. The expression level of rat IL-6 mRNA was evaluated using quantitative real-time PCR based on specific sets of primers and probes (Assays-on-Demand Gene Expression Products, Applied Biosystems, Foster City, CA, USA). B2M was used as a housekeeping gene to normalize values. Each reaction consisted of $1 \times$ TaqMan Universal PCR Master Mix (Applied Biosystems), $1 \times$ Assays-on-Demand Gene Expression Products (Rn00561420 $\mathrm{m} 1$ for rat IL-6; Rn00560865 m1 for rat B2MG), and $2 \mu \mathrm{l}$ cDNA in a total volume of $50 \mu \mathrm{l}$ using the following parameters with an ABI PRISM 7000 Sequence Detection System (Applied Biosystems): $95^{\circ} \mathrm{C}$ for $10 \mathrm{~min}, 40$ cycles at $95^{\circ} \mathrm{C}$ for $15 \mathrm{~s}$, and $60^{\circ} \mathrm{C}$ for $1 \mathrm{~min}$. The above assays involved specific sets of primers and TaqMan probe spanning exon/exon junctions and, therefore, should not have been influenced by DNA contamination. Data were collected and recorded by ABI PRISM 7000 SDS Software (Applied Biosystems) and expressed as a function of threshold cycle $\left(C_{\mathrm{T}}\right)$. Using diluted samples, the amplification efficacies for each gene of interest and the housekeeping gene amplimers were found to be identical.

\section{Relative quantitative gene expression}

Relative quantitative gene expression was calculated with the $2^{-\Delta \Delta C_{\mathrm{T}}}$ method (Livak \& Schmittgen 2001). In brief, for each sample assayed, the $C_{\mathrm{T}}$ for reactions amplifying a gene of 
interest (rat IL-6) and a housekeeping gene (rat B2MG) was determined. The gene of interest $C_{\mathrm{T}}$ for each sample was corrected by subtracting the $C_{\mathrm{T}}$ for the housekeeping gene $\left(\Delta C_{\mathrm{T}}\right)$. Untreated controls were chosen as reference samples, and the $\Delta C_{\mathrm{T}}$ for all experimental samples was reduced by the average $\Delta C_{\mathrm{T}}$ for the control samples $\left(\Delta \Delta C_{\mathrm{T}}\right)$. Finally,
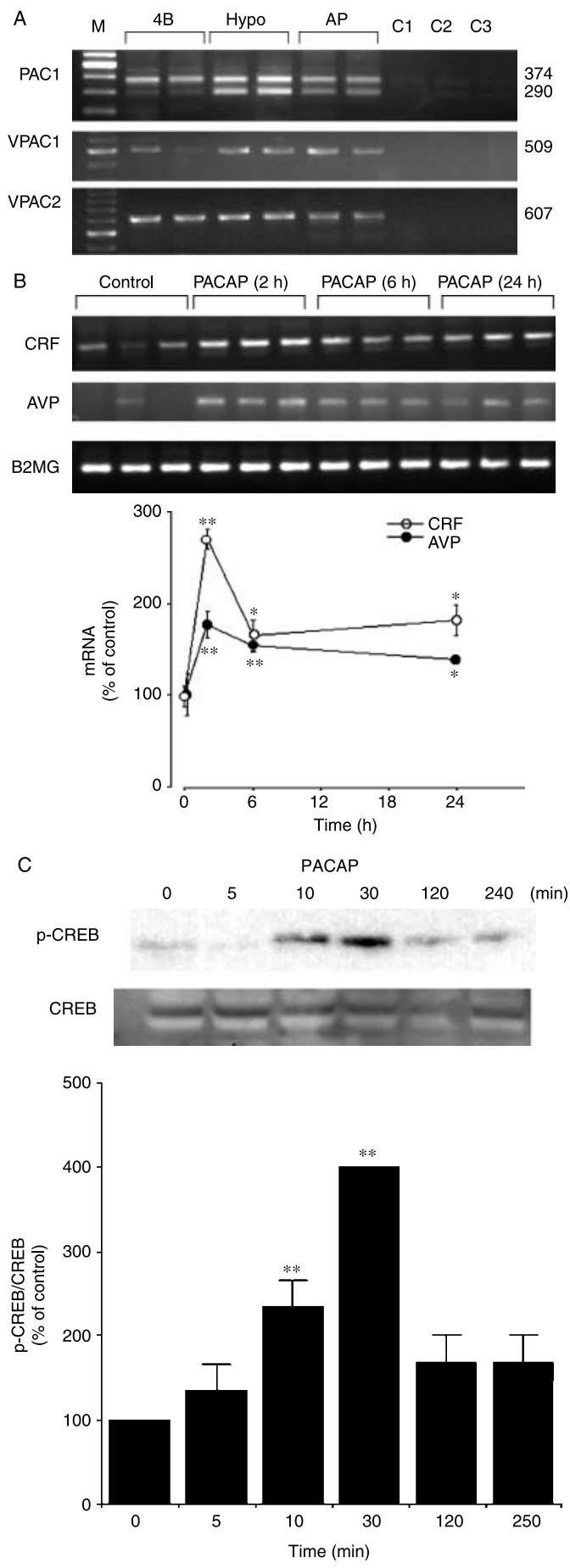

Journal of Endocrinology (2007) 195, 199-211 experimental mRNA abundance relative to control mRNA abundance was calculated by the formula $2^{-\Delta \Delta C_{\mathrm{T}}}$.

\section{Western blot analysis}

After treatment with PACAP, cells were washed twice with PBS and lysed with Laemmli sample buffer. Cell debris was pelleted by centrifugation, and the supernatant was recovered. Samples were boiled and subjected to electrophoresis on a gradient (4-20\%) polyacrylamide gel. Proteins were transferred to a polyvinylidene difluoride membrane (Daiichi Kagaku, Tokyo, Japan). After blocking by Detector Block blocking buffer (Kirkegaard \& Perry Laboratories, Gaithersburg, MD, USA), the membrane was incubated for $1 \mathrm{~h}$ with a rabbit anti-CREbinding protein (CREB) and anti-phosphorylated (p)-CREB antibodies (Cell Signaling Technology, Beverly, MA, USA), or anti-monoclonal IL-6 (BioSource International Inc.), washed with PBS containing $0 \cdot 05 \%$ Tween 20 , and incubated with horseradish peroxidase (HRP)-labeled anti-rabbit IgG (Daiichi Kagaku). Detection was performed using a chemiluminescent substrate Super-signal WestPico (Pierce Chemical Co., Rockford, IL, USA), and the membrane was exposed to BioMax film (Eastman Kodak Co.) followed by quantitative analysis using the NIH image software 1.61. The results are expressed as corrected arbitrary units.

\section{IL- 6 assay}

Serum-starved $4 \mathrm{~B}$ cells were incubated at $37^{\circ} \mathrm{C}$ for $48 \mathrm{~h}$ with the indicated concentrations of each peptide. The medium was then aspirated and IL-6 levels in the supernatants were measured using commercial IL-6 ELISA kits (Biosource International). All samples from each experiment were determined in the same assay.

\section{Statistical analysis}

All values are expressed as the mean \pm s.E.M. Statistical analyses of data were performed using one-way ANOVA, followed by Bonferroni/Dunn post hoc test. The level of statistical significance was set at $P<0 \cdot 05$.

Figure 1 Expression of CRF, AVP, and receptors for PACAP. Cells were treated in triplicate in each experiment, with the average of three independent experiments shown in figures. Statistical analyses were performed using ANOVA, followed by post hoc test. ${ }^{*} P<0 \cdot 05,{ }^{* *} P<0 \cdot 005$ (when compared with control). (A)

Expression of PAC1, VPAC1, and VPAC2 receptors in $4 B$ cells. Short isoform (290 bp) and a variant with a single $84 \mathrm{bp}$ insert (374 bp) of PAC1 receptor were detected by RT-PCR. 4B, 4B cells; Hypo, hypothalamus; $\mathrm{AP}$, anterior pituitary; $\mathrm{C} 1$, negative control for $4 \mathrm{~B}$; C2, negative control for hypo; $C 3$, negative control for AP. (B) Effects of PACAP on CRF and AVP mRNA levels. The $4 \mathrm{~B}$ cells were stimulated with $100 \mathrm{nM}$ PACAP for 2, 6, and $24 \mathrm{~h}$. Expression of CRF and AVP mRNA was examined by RT-PCR. (C) Effects of PACAP on CREB phosphorylation. The $4 \mathrm{~B}$ cells were stimulated with $100 \mathrm{nM}$ PACAP for the duration shown. CREB phosphorylation was examined by western blot analysis. 


\section{Results}

Expression of CRF, AVP, and receptors for PACAP $m R N A$ in $4 B$ cells

PAC1 receptor gene expression was detected in 4B cells, hypothalamus, and anterior pituitary tissues (Fig. 1A). PAC1 receptor has a short isoform (290 bp) and a variant with a single $84 \mathrm{bp}$ insert $(374 \mathrm{bp})$. Expression levels of VPAC1 receptor were very low in 4B cells, while VPAC2 was detected in 4B cells and rat hypothalamus.

Expression of both CRF and AVP mRNA was examined by RT-PCR. Basal levels of both mRNA were very low or undetectable, while PACAP significantly increased both CRF and AVP mRNA levels from 2 to $24 \mathrm{~h}$ after experiment in $4 \mathrm{~B}$ cells (Fig. 1B). The maximal effect of PACAP was observed at $2 \mathrm{~h}$ after experiment.

To determine whether PACAP affected CREB phosphorylation, 4B cells were incubated with PACAP. As shown in Fig. 1C, incubation with $100 \mathrm{nM}$ PACAP significantly increased CREB phosphorylation from 10 to $30 \mathrm{~min}$ after the addition.

\section{Effects of PACAP on CRF or AVP $5^{\prime}$-promoter activity in $4 B$ cells}

We examined the impact of PACAP on the time- and dosedependent changes in CRF $5^{\prime}$-promoter activity using $4 \mathrm{~B}$ cells transfected with CRF-907luc. The time course study showed that PACAP significantly increased CRF $5^{\prime}$-promoter activity
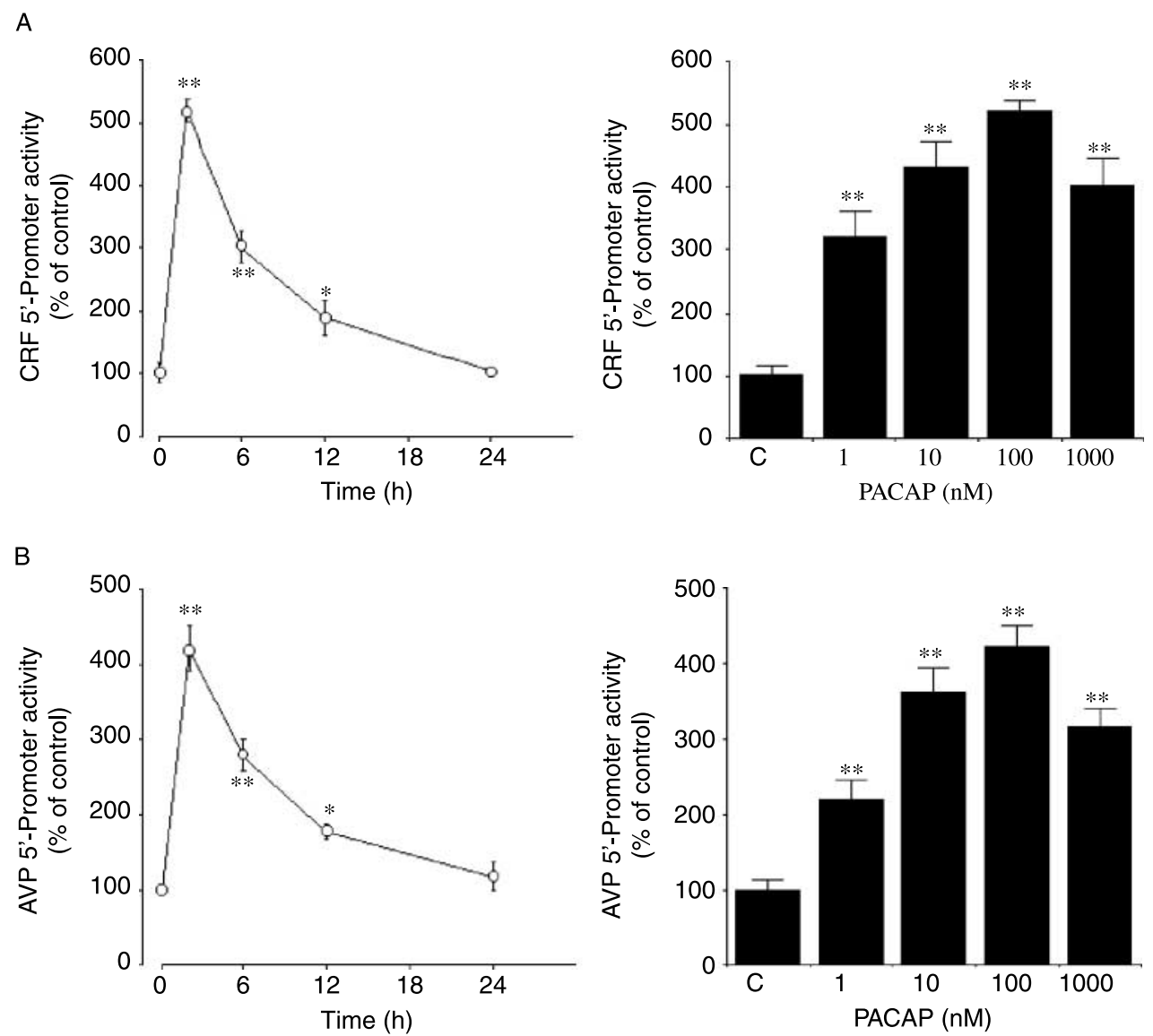

Figure 2 Effects of PACAP on CRF or AVP 5'-promoter activity in 4B cells. Cells treated with medium alone are indicated as C. Statistical analyses were performed using one-way ANOVA, followed by post hoc test. ${ }^{*} P<0 \cdot 05,{ }^{* *} P<0 \cdot 005$ (when compared with control (C)). (A) Time- and dose-dependent changes in PACAPinduced CRF 5'-promoter activity. (A(i)) Time-dependent changes in PACAP-induced CRF 5'-promoter activity. Cells were incubated with medium containing $100 \mathrm{nM}$ PACAP. (A(ii)) Dose-dependent changes in PACAP-induced CRF 5'-promoter activity. Cells were incubated for $2 \mathrm{~h}$ with medium containing $1 \mathrm{nM}$ to $1 \mu \mathrm{M}$ PACAP. (B) Time- and dose-dependent changes in PACAP-induced AVP 5'-promoter activity. (B(i))Time-dependent changes in PACAP-induced AVP 5'-promoter activity. Cells were incubated with medium containing 100 nM PACAP. (B(ii)) Dose-dependent changes in PACAP-induced AVP 5'-promoter activity. Cells were incubated for $2 \mathrm{~h}$ with medium containing $1 \mathrm{nM}$ to $1 \mu \mathrm{M}$ PACAP. 


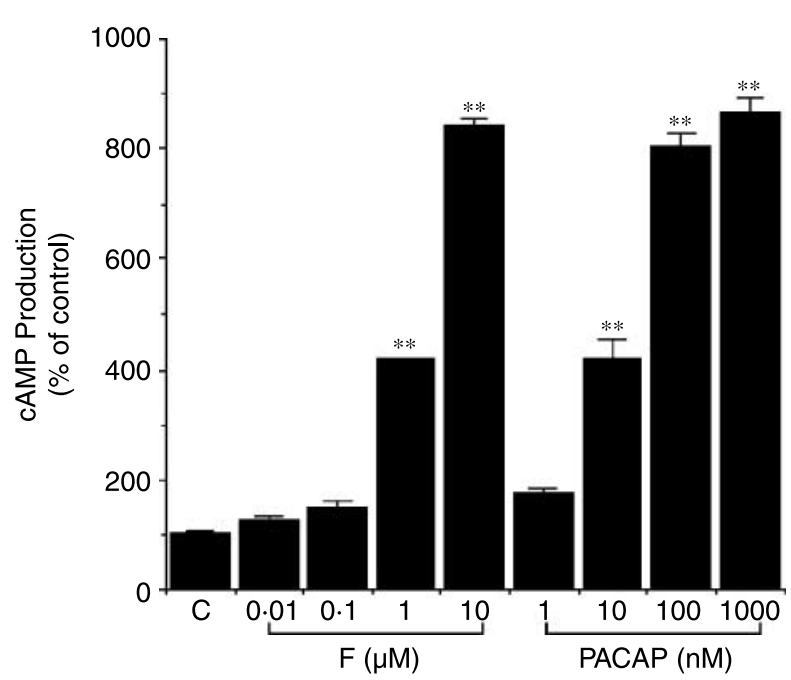

Figure 3 Effects of PACAP on cAMP accumulation in $4 B$ cells. ${ }^{* *} P<0.005$ (when compared with control $(\mathrm{C})$ ). Cells were preincubated for 20 min with medium containing $0 \cdot 1 \mathrm{mM} 3$-isobutyl1-methylxanthine, followed by the addition of forskolin (F) or PACAP. Cells were then incubated for 20 min with medium alone (control), or with medium containing F or PACAP. The level of intracellular cAMP was measured by cAMP EIA.

(ANOVA; $P<0 \cdot 0001$; Fig. 2A(i)). The maximal effect of PACAP occurred at $2 \mathrm{~h}$ after experiment, with an approximate fivefold increase in CRF $5^{\prime}$-promoter activity when compared with the basal level in CRF-907luc $(P<0 \cdot 005)$. PACAP stimulated CRF $5^{\prime}$-promoter activity in a dose-dependent manner with significant enhancing effects of PACAP observed at $1 \mathrm{nM}$ to $1 \mu \mathrm{M}$ (ANOVA; $P<0 \cdot 0001$ ) (Fig. 2A(ii)).

Next, we examined the impact of PACAP on the time- and dose-dependent changes in AVP luciferase activity using 4B cells transfected with AVP-803luc (Fig. 2B). The time course study showed that PACAP significantly increased AVP $5^{\prime}$-promoter activity (ANOVA; $P<0 \cdot 0001$ ) (Fig. 2B(i)). The maximal effect of PACAP was observed $2 \mathrm{~h}$ after the experiment, with an approximate fourfold increase when compared with the basal level in AVP-803luc $(P<0 \cdot 005)$. PACAP stimulated AVP luciferase activity in a dosedependent manner, with significant stimulatory effects at $1 \mathrm{nM}$ to $1 \mu \mathrm{M}$ (ANOVA; $P<0 \cdot 0001$; Fig. $2 \mathrm{~B}$ (ii)).

\section{Effects of PACAP on $C A M P$ accumulation in $4 B$ cells}

Figure 3 shows the levels of cAMP production following PACAP stimulation of $4 \mathrm{~B}$ cells. Both forskolin and PACAP induced intracellular cAMP production in a dose-dependent manner. Significant stimulatory effects of PACAP were observed at $10 \mathrm{nM}$ to $1 \mu \mathrm{M}$.

Effects of a PKA or extracellular signal-related kinases inhibitor on PACAP-induced CRF or AVP $5^{\prime}$-promoter activity in $4 B$ cells

To determine whether PKA pathway is involved in the PACAP-induced CRF or AVP $5^{\prime}$-promoter activity, 4B cells were incubated with $\mathrm{H} 89$, a potent PKA inhibitor. As shown in Fig. 4, the stimulatory effects of $100 \mathrm{nM}$ PACAP on both activities were partially inhibited by treatment with $1 \mu \mathrm{M}$ H89, while these of a smaller dose, $10 \mathrm{nM}$ PACAP were completely done. The effects of $10 \mathrm{nM}$ PACAP on both CRF and AVP promoter activities were not inhibited by $10 \mu \mathrm{M}$ PD98059, a selective mitogen-activated protein (MAP) kinase kinase extracellular signal-related kinases inhibitor.

\section{Effects of forskolin or PACAP on IL- $65^{\prime}$-promoter activity in $4 B$ cells}

Forskolin or PACAP may stimulate IL-6 gene expression in $4 \mathrm{~B}$ cells. Therefore, we examined the time- and dosedependency of forskolin and PACAP on IL-6 $5^{\prime}$-promoter
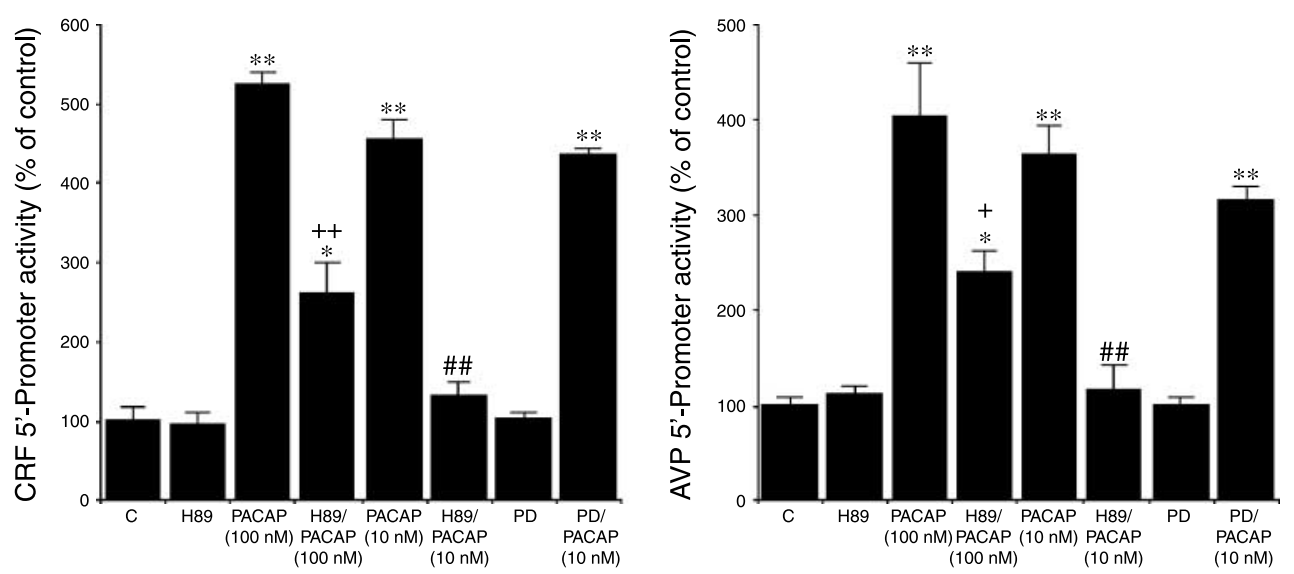

Figure 4 Effects of a PKA or ERK inhibitor on PACAP-induced CRF or AVP 5 '-promoter activity in 4B cells. ${ }^{*} P<0 \cdot 05,{ }^{* *} P<0 \cdot 005$ (when compared with control $\left.(C)\right) .{ }^{+} P<0 \cdot 05,{ }^{+}+P<0 \cdot 005$ (when compared with 100 nM PACAP). ${ }^{\#} P<0 \cdot 005$ (when compared with 10 nM PACAP). Cells were pre-incubated with medium containing $1 \mu \mathrm{M} \mathrm{H} 89,10 \mu \mathrm{M}$ PD98059, or vehicle for $30 \mathrm{~min}$ and then incubated for $2 \mathrm{~h}$ with medium containing 10 or 100 nM PACAP, or vehicle. Cells treated with PD98059 are indicated as PD. 

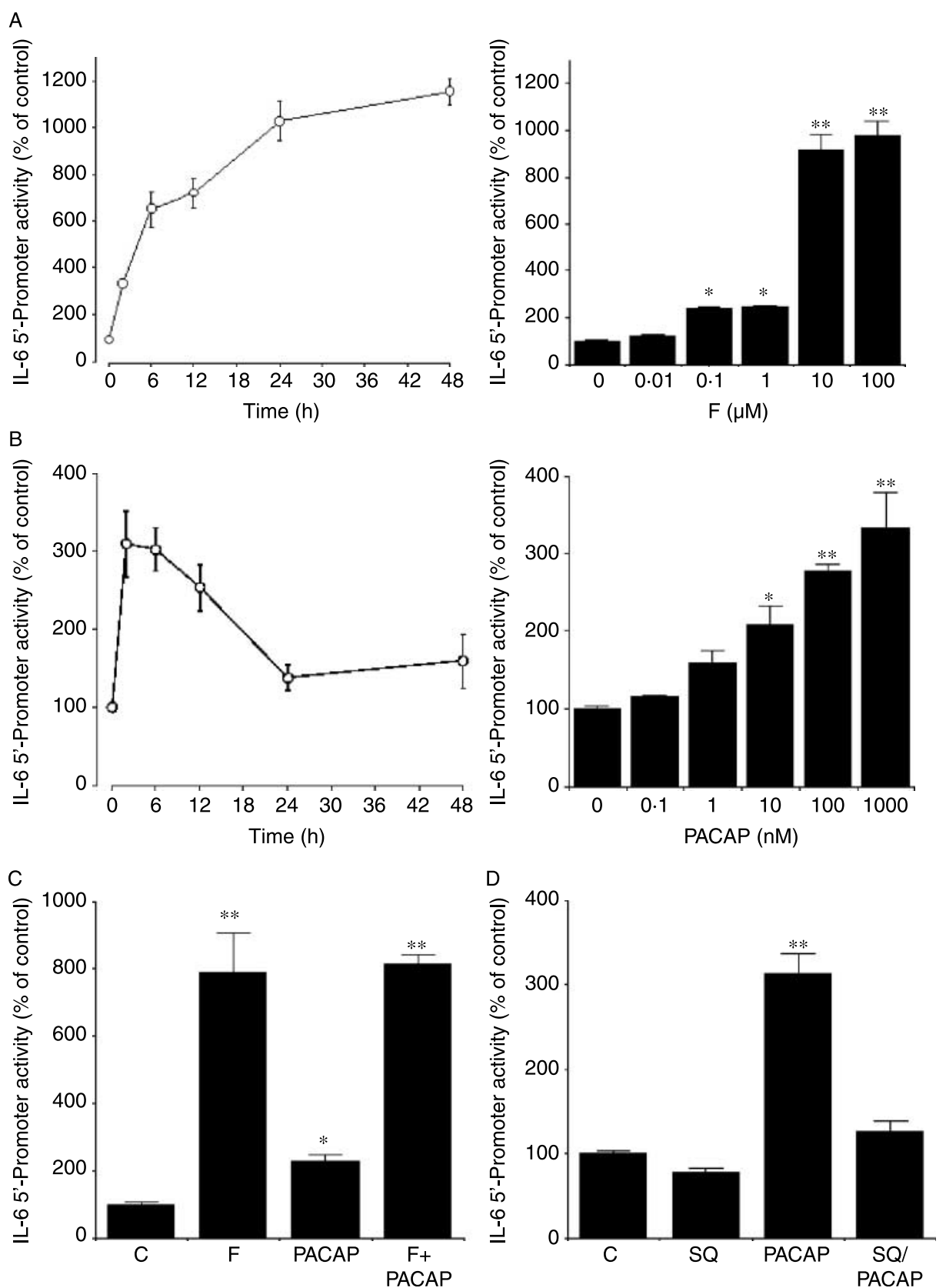

Figure 5 Effects of forskolin or PACAP on IL-6 5'-promoter activity in 4B cells. ${ }^{*} P<0 \cdot 05,{ }^{* *} P<0 \cdot 005$ (when compared with control (C)). (A) Time- and dose-dependent changes in forskolin-induced IL- $65^{\prime}$-promoter activity. (A(i)) Time-dependent changes in forskolin-induced IL-6 $5^{\prime}$-promoter activity. Cells were incubated with medium containing $10 \mu \mathrm{M}$ forskolin. (A(ii)) Dose-dependent changes in forskolin-induced IL-6 5' promoter activity. Cells were incubated for $24 \mathrm{~h}$ with medium containing $0 \cdot 01$ to $100 \mu \mathrm{M}$ forskolin (F). (B) Time- and dose-dependent changes in PACAP-induced IL-6 5'-promoter activity. (B(i)) Time-dependent changes in PACAP-induced IL-6 5'-promoter activity. Cells were incubated with medium containing 100 nM PACAP. (B(ii)) Dose-dependent changes in PACAP-induced IL-6 5'-promoter activity. Cells were incubated for $2 \mathrm{~h}$ with medium containing $0 \cdot 1 \mathrm{nM}$ to $1 \mu \mathrm{M}$ PACAP. (C) Effect of PACAP on forskolin-induced IL-6 5'-promoter activity. Cells were incubated for $6 \mathrm{~h}$ with medium alone $(\mathrm{C})$ or medium containing $100 \mu \mathrm{M}$ forskolin and/or $1 \mu \mathrm{M}$ PACAP. (D) Effects of an adenylate cyclase inhibitor on PACAP-induced IL-6 $5^{\prime}$-promoter activity. Cells were pre-incubated with medium containing $100 \mu \mathrm{M} \mathrm{SQ} 22536$, or vehicle for $30 \mathrm{~min}$ and then incubated for $2 \mathrm{~h}$ with medium containing $100 \mathrm{nM}$ PACAP, or vehicle. Cells treated with SQ22536 are indicated as SQ. 

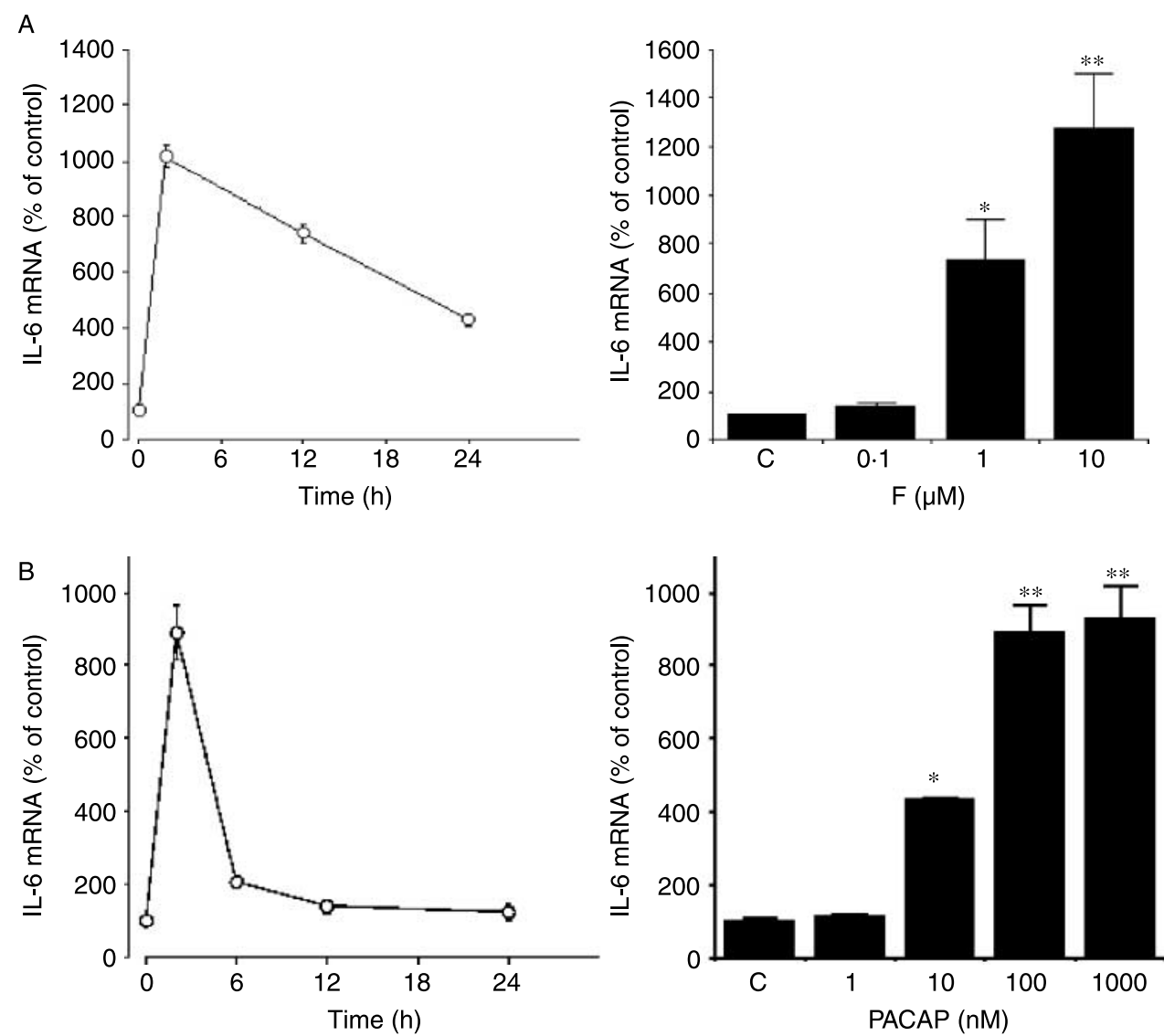

Figure 6 Effects of forskolin or PACAP on IL-6 mRNA levels in $4 \mathrm{~B}$ cells. ${ }^{*} P<0 \cdot 05,{ }^{*} P<0 \cdot 005$ (when compared with control (C)). (A) Time- and dose-dependent changes in forskolin-induced IL- 6 mRNA levels. (A(i)) Time-dependent changes in forskolin-induced IL-6 mRNA levels. Cells were incubated with medium containing $10 \mu \mathrm{M}$ forskolin. (A(ii)) Dose-dependent changes in forskolin-induced IL-6 mRNA levels. Cells were incubated for $2 \mathrm{~h}$ with medium containing $0 \cdot 1-10 \mu \mathrm{M}$ forskolin (F). (B) Time- and dose-dependent changes in PACAP-induced IL-6 mRNA levels. (B(i)) Time-dependent changes in PACAP-induced IL-6 mRNA levels. Cells were incubated with medium containing 100 nM PACAP. (B(ii)) Dose-dependent changes in PACAP-induced IL-6 mRNA levels. Cells were incubated for $2 \mathrm{~h}$ with medium containing $1 \mathrm{nM}$ to $1 \mu \mathrm{M}$ PACAP.

activity (Fig. 5A). The time course study revealed gradual increases in IL-6 $5^{\prime}$-promoter activity in the presence of $10 \mu \mathrm{M}$ forskolin. Significant stimulatory effects of forskolin were observed at $0 \cdot 1-100 \mu \mathrm{M}$.

We next examined the effect of PACAP on the timeand dose-dependent changes in IL-6 5'-promoter activity, using 4B cells transfected with IL-6luc (Fig. 5B). The maximal effects of PACAP were observed at 2 and $6 \mathrm{~h}$ after experiment, with an approximate threefold increase when compared with the basal level. PACAP stimulated IL-6 5'-promoter activity in a dose-dependent manner with significant stimulatory effects observed at $10 \mathrm{nM}$ to $1 \mu \mathrm{M}$.

When PACAP was simultaneously used with forskolin, the combination showed no additive effect on IL- $65^{\prime}$-promoter activity (Fig. 5C).
To determine whether an adenylate cyclase pathway was involved in PACAP-induced IL-6 5' -promoter activity, 4B cells were pre-incubated for $30 \mathrm{~min}$ with $100 \mu \mathrm{M}$ SQ22536, an adenylate cyclase inhibitor. As shown in Fig. 5D, treatment with SQ22536 significantly inhibited IL-6 $5^{\prime}$-promoter activity.

\section{Effects of forskolin or PACAP on IL-6 mRNA levels in $4 B$ cells}

Next, we investigated the modulation of IL-6 mRNA levels by forskolin and PACAP. The maximal effect of forskolin on IL-6 mRNA levels occurred at $2 \mathrm{~h}$ after experiment, with an approximate tenfold increase when compared with the basal level (Fig. 6A). Significant stimulatory effects of forskolin were observed at 1 and $10 \mu \mathrm{M}$.

We also examined time- and dose-dependent changes in IL-6 mRNA levels in the presence of PACAP (Fig. 6B). 


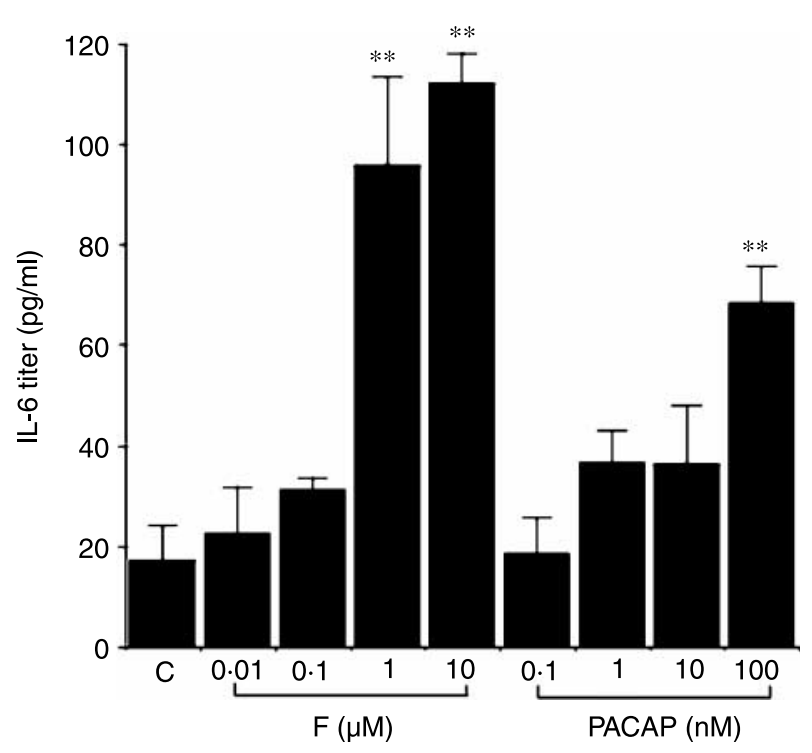

Figure 7 Effects of PACAP on IL-6 production in $4 \mathrm{~B}$ cells. ${ }^{* *} P<0.005$ (when compared with control $(\mathrm{C})$ ). Cells were incubated for $48 \mathrm{~h}$ with medium alone (control), or with medium containing forskolin (F) or PACAP. The titers of IL-6 in the culture supernatants were measured by IL-6 ELISA.

Maximal stimulation by PACAP was observed at $2 \mathrm{~h}$ after experiment, with an approximate ninefold increase of IL-6 mRNA levels. PACAP stimulated IL-6 mRNA levels in a dose-dependent manner with significant stimulation at $10 \mathrm{nM}$ to $1 \mu \mathrm{M}$.

\section{Effects of PACAP on IL-6 production in $4 B$ cells}

To examine whether PACAP induced a functional response in the $4 \mathrm{~B}$ cells, we examined the effects of PACAP on IL- 6 output levels or production (Fig. 7). Incubation with $0.01 \mathrm{nM}$ to $10 \mu \mathrm{M}$ forskolin or $0 \cdot 1$ to $100 \mathrm{nM}$ PACAP increased IL-6 output levels in a dose-dependent manner (ANOVA; $P<0 \cdot 0001)$. PACAP stimulation was significant at $100 \mathrm{nM}$.

\section{Effects of IL- 6 on CRF and AVP 5'-promoter activities in $4 B$ cells}

IL-6 is a candidate modulator of CRF and AVP gene expression. Therefore, we examined the time- and dosedependency of the IL-6 effects on both CRF and AVP $5^{\prime}$-promoter activities. To examine CRF 5'-promoter activity, 4B cells transfected with CRF-907luc were incubated with IL-6 (Fig. 8A). The time course revealed a gradual increase in CRF $5^{\prime}$-promoter following exposure to $5 \mathrm{nM}$ IL-6. Maximal stimulation by IL-6 occurred after $24 \mathrm{~h}$, with an approximate twofold increase when compared with the basal level. IL-6 stimulation of CRF $5^{\prime}$-promoter was dose dependent with significant stimulatory effects observed at $500 \mathrm{pM}$.
Next, 4B cells transfected with AVP-803luc were incubated with IL-6 to examine changes in AVP $5^{\prime}$-promoter activity (Fig. 8B). There were gradual increases in AVP $5^{\prime}$-promoter activity in the presence of $5 \mathrm{nM}$ IL-6. The maximal effect of IL-6 was observed after $24 \mathrm{~h}$, with an approximate twofold increase when compared with the basal level. IL-6 stimulated AVP 5'-promoter activity in a dosedependent manner, with $500 \mathrm{pM}$ inducing significant stimulation.

\section{Effects of anti-IL-6 Ab on PACAP-induced CRF or AVP} $5^{\prime}$-promoter activity in $4 B$ cells

PACAP (100 nM) stimulated IL-6 protein expression from 2 to $24 \mathrm{~h}$ after experiment in $4 \mathrm{~B}$ cells (Fig. 9A).

Finally, to determine whether endogenous IL-6 production is involved in the PACAP-induced CRF or AVP $5^{\prime}$-promoter activity, 4B cells were pre-incubated for 30 min with anti-IL-6 MAB, and then incubated for $2 \mathrm{~h}$ with 10 or 100 nM PACAP. As shown in Fig. 9B, the stimulatory effects of $100 \mathrm{nM}$ or a smaller dose, $10 \mathrm{nM}$, PACAP on both activities were significantly, but not completely, inhibited by treatment with the anti-IL-6 MAB.

\section{Discussion}

In this study, we first found that PACAP stimulated activity of both CRF and AVP promoter in hypothalamic 4B cells. Although PACAP has been shown to modulate hypothalamic CRF gene expression in vivo (Grinevich et al. 1997), it was difficult to study the mechanism regulating CRF transcription in parvocellular neurons because of the lack of availability of a representative cell line. We used a homologous hypothalamic $4 \mathrm{~B}$ cell, which shows the characteristics of the parvocellular cells of the PVN, because the cells were shown to express CRF, AVP, and $\mathrm{CRF}_{1}$ and glucocorticoid receptors (Kasckow et al. 2003b). In this and other recent studies (Liu et al. 2006), basal levels of both CRF and AVP mRNA were very low or undetectable in the $4 \mathrm{~B}$ cells, presumably caused by changes in the cell condition through current passages of the cells, while PACAP stimulated both CRF and AVP mRNA levels in 4B cells. PACAP induced intracellular cAMP production in hypothalamic $4 \mathrm{~B}$ cells and stimulated CRF gene transcription via the cAMP-dependent pathway. Indeed, nerve fibers containing PACAP connect to CRF neurons (Hannibal et al. 1995, Legradi et al. 1998). Other studies also suggest that PACAP stimulates CRF gene via the cAMP/PKA signaling pathway (Agarwal et al. 2005). In hypothalamic 4B cells, the cAMP-PKA pathway was involved in PACAP-induced CRF stimulation of gene transcription. Activation of the PKA pathway, causing phosphorylation of CREB, acts on the CRF promoter (Seasholtz et al. 1988, Spengler et al. 1992, Itoi et al. 1996). A functional CRE in the $5^{\prime}$-promoter region takes a part in regulating CRF gene expression (Seasholtz et al. 1988, Spengler et al. 1992). H89, a PKA inhibitor, completely 

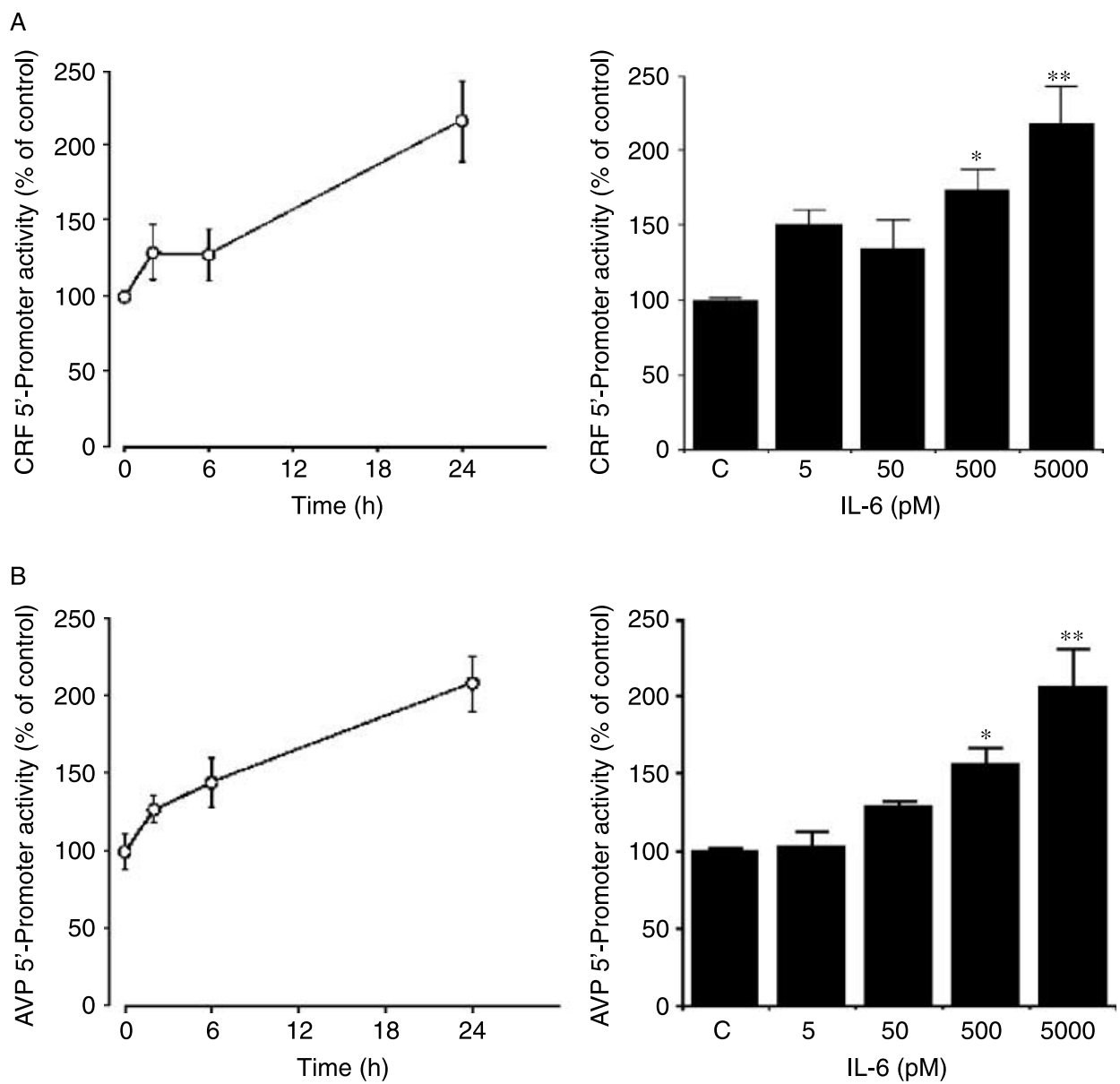

Figure 8 Effects of IL- 6 on CRF or AVP 5 -promoter activity in $4 \mathrm{~B}$ cells. ${ }^{*} P<0 \cdot 05,{ }^{* *} P<0 \cdot 005$ (when compared with control (C)). (A) Time- and dose-dependent changes in IL-6-induced CRF $5^{\prime}$-promoter activity. (A(i)) Time course of IL-6-induced CRF 5'-promoter activity. Cells were incubated with medium containing $5 \mathrm{nM}$ IL-6. (A(ii)) Dose-dependent changes in IL-6-induced CRF luciferase activity. Cells were incubated for $24 \mathrm{~h}$ with medium containing $5 \mathrm{pM}$ to $5 \mathrm{nM} \mathrm{IL-6.} \mathrm{(B)} \mathrm{Time-} \mathrm{and} \mathrm{dose-dependent} \mathrm{changes} \mathrm{in}$ IL-6-induced AVP 5'-promoter activity. (B(i)) Time course of IL-6-induced AVP $5^{\prime}$-promoter activity. Cells were incubated with medium containing $5 \mathrm{nM} \mathrm{IL-6.} \mathrm{(B(ii))} \mathrm{Dose-dependent} \mathrm{changes} \mathrm{in} \mathrm{IL-6-induced} \mathrm{AVP}$ $5^{\prime}$-promoter activity. Cells were incubated for $24 \mathrm{~h}$ with medium containing $5 \mathrm{pM}$ to $5 \mathrm{nM}$ IL-6.

blocked a smaller dose of PACAP-induced CRF stimulation of gene transcription in hypothalamic $4 \mathrm{~B}$ cells. However, the inhibitor did not completely block a larger dose of PACAPinduced CRF stimulation, suggesting the limitation of the inhibitor. Otherwise, it is possible that an additional pathway may be involved in this regulation. The difference between CRF/AVP promoter activity and cAMP response to PACAP also may suggest that the effect of PACAP is mediated by other signals in addition to cAMP.

PACAP also stimulated both AVP gene transcription and mRNA expression via the cAMP-PKA pathway in hypothalamic 4B cells. Gene transcription of AVP is stimulated by Fos/Jun family member proteins through an activation protein 1 (AP1) site in neuroblastoma cells (Yoshida et al. 2006). This effect is achieved via both PKA and protein kinase
C signaling pathways. Therefore, our results are consistent with those of the prior study showing that intracellular cAMP production is involved in the stimulation of AVP gene transcription via the PKA pathway in hypothalamic 4B cells. PACAP is detected in nerve terminals that innervate AVPcontaining neurons in the rat hypothalamus (Shioda et al. 1997b), and its receptor mRNA is highly expressed in AVP-containing neurons (Shioda et al. 1997b). Another report demonstrated that PAC1 receptors were expressed in the parvocellular and magnocellular subdivisions of the PVN (Nomura et al. 1996). The 4B cells also expressed PAC1 and VPAC receptors. Therefore, activation of PAC1 or VPAC receptors by PACAP induces production of intracellular cAMP, activating the transcription of AVP gene in hypothalamic cells. Taken together, we propose that 
A

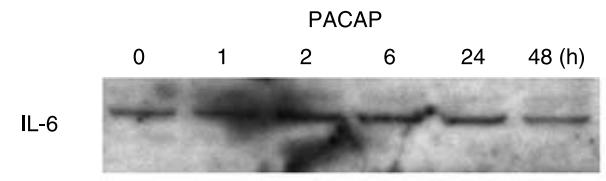

B
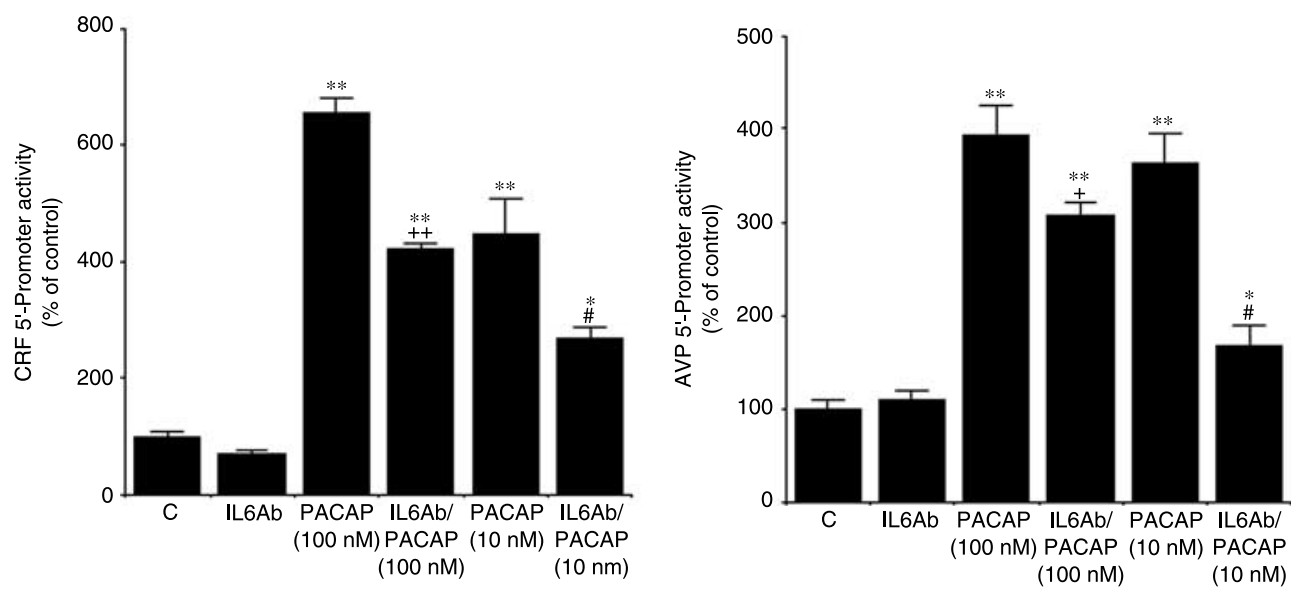

Figure 9 Effects of anti-IL-6 Ab on PACAP-induced CRF or AVP 5'-promoter activity in 4B cells. ${ }^{* *} P<0 \cdot 005$ (when compared with control $\left.(\mathrm{C})\right){ }^{+} P<0 \cdot 05,{ }^{+}{ }^{+} P<0.005$ (when compared with $100 \mathrm{nM}$ PACAP). ${ }^{\#} P<0.05$ (when compared with $10 \mathrm{nM}$ PACAP). (A) Effects of PACAP on IL-6 protein levels. The $4 \mathrm{~B}$ cells were stimulated with $100 \mathrm{nM}$ PACAP for duration shown. Expression of IL-6 protein was examined by western blot analysis. (B) Cells were pre-incubated with medium containing anti-IL-6 Ab or control $\operatorname{lgG}$ for $30 \mathrm{~min}$ and then incubated for $2 \mathrm{~h}$ with medium containing 10 or $100 \mathrm{nM}$ PACAP or vehicle. Cells treated with control $\operatorname{lgG}$ are indicated as C.

PACAP-induced intracellular cAMP production is involved in stimulating the transcription of both CRF and AVP genes at least via the PKA pathway in hypothalamic $4 \mathrm{~B}$ cells.

The role of PACAP in the PVN of the hypothalamus has not been clearly determined, although PACAP might contribute to stress responses through CRF and AVP stimulation. The extended amygdala and the bed nuclei of the stria terminalis are identified as innervation sites of PACAP neurons, suggesting an important role in stress responses (Piggins et al. 1996, Kozicz \& Arimura 2002). PACAP also stimulates cAMP production in the AP. PACAP, therefore, could regulate pituitary corticotrophs directly (Boutillier et al. 1994). CRF and AVP neurons in the parvocellular region of PVN project to the external zone of the ME (Seasholtz et al. 1988, Gonzalez-Hernandez et al. 2006). Furthermore, AVP and CRF in parvocellular PVN neurons exert synergistic effects on ACTH secretion from the AP (Gillies et al. 1982, Mouri et al. 1993). Therefore, PACAP may contribute to stress responses through stimulation of CRF and AVP neurons of the hypothalamus, causing ACTH secretion.

The treatment with both PACAP and forskolin showed no additive effect on IL-6 5'-promoter activity. An adenylate cyclase inhibitor significantly inhibited PACAP-induced IL-6 $5^{\prime}$-promoter activity. Therefore, PACAP may stimulate IL-6 production through intracellular cAMP pathway. On the other hand, it is possible that the differences in the activation of IL-6 promoter between PACAP and forskolin may suggest the differences in signal pathway, in addition to cAMP, in the IL-6 regulation.

Cytokines affect the HPA axis at multiple levels (Dunn 2004). Silverman et al. (2004). demonstrated that IL-6 was able to activate the HPA axis directly by actions on the hypothalamus, the pituitary, and the adrenal cortex. IL-6 and its receptor mRNA levels in the hypothalamus are modulated by an acute stress or changes in the HPA axis (Komori et al. 2003). Therefore, IL-6 in the hypothalamus is also a candidate for stimulation of CRF and AVP gene expression. PACAP could participate in the regulation of CRF and AVP genes via IL-6 production. For example, both forskolin and PACAP stimulated IL-6 promoter activity, IL-6 mRNA, and protein release. Therefore, PACAP stimulates IL-6 synthesis and secretion. PACAP increased IL- 6 output levels to $70 \mathrm{pg} / \mathrm{ml}$ which would correspond to about $3.5 \mathrm{pM}$ in the medium, while significant stimulatory effects on both CRF and AVP promoter activities required the treatment with at least 500 pM IL-6 in our study. This result suggests that IL-6 may not be the only stimulus in response to PACAP. However, we found that the stimulatory effects of PACAP on both activities were significantly inhibited by treatment with the 
anti-IL-6 MAB. Therefore, we propose that endogenous IL-6 production is involved in the PACAP-induced CRF and AVP $5^{\prime}$-promoter activities, and IL-6 stimulates transcription of both genes in an autocrine manner in hypothalamic 4B cells. Considering the delayed response to IL-6, and the partial inhibition of PACAP effects by IL-6 Ab, IL-6 may be important to sustain the activity of CRF and AVP promoter. Finally, note that subpopulations of parvocellular cells coexpress CRF, AVP, and IL-6, and project to the external layer of the ME (Gonzalez-Hernandez et al. 2006). Thus, it is possible that IL-6, produced in the hypothalamus, both directly and indirectly through CRF and AVP, stimulates ACTH secretion in pituitary corticotrophs.

In conclusion, this study demonstrated that PACAP stimulates transcription of CRF and AVP genes via a cAMP-dependent PKA pathway in hypothalamic 4B cells. The PACAP-induced intracellular cAMP pathway was also involved in the regulation of IL-6 gene transcription and protein production in hypothalamic $4 \mathrm{~B}$ cells.

\section{Acknowledgements}

We thank Dr Ken Itoh's laboratory (Center for Advanced Medical Research) for technical assistance. K K is supported by a grant from the Funds for the Promotion of Aomori Medical Research. This work was also supported in part by Health and Labor Science Research Grants (Research on Measures for Intractable Diseases) from the Ministry of Health, Labor, and Welfare of Japan, and by a grant to T S from the Ministry of Education, Science and Culture of Japan (No. 18591014). The authors declare that there is no conflict of interest that would prejudice the impartiality of this scientific work.

\section{References}

Agarwal A, Halvorson LM \& Legradi G 2005 Pituitary adenylate cyclaseactivating polypeptide (PACAP) mimics neuroendocrine and behavioral manifestations of stress: evidence for PKA-mediated expression of the corticotropin-releasing hormone (CRH) gene. Brain Research. Molecular Brain Research 138 45-57.

Ajpru S, McArthur AJ, Piggins HD \& Sugden D 2002 Identification of PAC1 receptor isoform mRNAs by real-time PCR in rat suprachiasmatic nucleus. Brain Research. Molecular Brain Research 105 29-37.

Aoki Y, Iwasaki Y, Katahira M, Oiso Y \& Saito H 1997 Regulation of the rat proopiomelanocortin gene expression in AtT-20 cells. II: Effects of the pituitary adenylate cyclase-activating polypeptide and vasoactive intestinal polypeptide. Endocrinology 138 1930-1934

Boutillier AL, Monnier D, Koch B \& Loeffler JP 1994 Pituitary adenyl cyclaseactivating peptide: a hypophysiotropic factor that stimulates proopiomelanocortin gene transcription, and proopiomelanocortin-derived peptide secretion in corticotropic cells. Neuroendocrinology 60 493-502.

Burbach JP, Luckman SM, Murphy D \& Gainer H 2001 Gene regulation in the magnocellular hypothalamo-neurohypophysial system. Physiological Reviews 81 1197-1267.

Castell JV, Gomez-Lechon MJ, David M, Andus T, Geiger T, Trullenque R, Fabra R \& Heinrich PC 1989 Interleukin-6 is the major regulator of acute phase protein synthesis in adult human hepatocytes. FEBS Letters 242 237-239.
Chaudhary P \& Baumann TK 2002 Expression of VPAC2 receptor and PAC1 receptor splice variants in the trigeminal ganglion of the adult rat. Brain Research. Molecular Brain Research 104 137-142.

Dunn AJ 2004 Interleukin-6 access to the axis. Endocrinology 145 3578-3579.

Ghorbel MT, Sharman G, Leroux M, Barrett T, Donovan DM, Becker KG \& Murphy D 2003 Microarray analysis reveals interleukin-6 as a novel secretory product of the hypothalamo-neurohypophyseal system. Journal of Biological Chemistry 278 19280-19285.

Gillies GE, Linton EA \& Lowry PJ 1982 Corticotropin releasing activity of the new CRF is potentiated several times by vasopressin. Nature 299 355-357.

Gonzalez-Hernandez T, Afonso-Oramas D, Cruz-Muros I, Barroso-Chinea P, Abreu P, del Mar Perez-Delgado M, Rancel-Torres N \& del Carmen Gonzalez M 2006 Interleukin-6 and nitric oxide synthase expression in the vasopressin and corticotrophin-releasing factor systems of the rat hypothalamus. Journal of Histochemistry and Cytochemistry 54 427-441.

Grinevich V, Fournier A \& Pelletier G 1997 Effects of pituitary adenylate cyclase-activating polypeptide (PACAP) on corticotropin-releasing hormone $(C R H)$ gene expression in the rat hypothalamic paraventricular nucleus. Brain Research 773 190-196.

Hannibal J, Mikkelsen JD, Fahrenkrug J \& Larsen PJ 1995 Pituitary adenylate cyclase-activating peptide gene expression in corticotropin-releasing factorcontaining parvicellular neurons of the rat hypothalamic paraventricular nucleus is induced by colchicine, but not by adrenalectomy, acute osmotic, ether, or restraint stress. Endocrinology 136 4116-4124.

Harmar AJ, Arimura A, Gozes I, Journot L, Laburthe M, Pisegna JR, Rawlings SR, Robberecht P, Said SI, Sreedharan SP et al. 1998 International Union of Pharmacology. XVIII. Nomenclature of receptors for vasoactive intestinal peptide and pituitary adenylate cyclase-activating polypeptide. Pharmacological Reviews 50 265-270.

Itoi K, Horiba N, Tozawa F, Sakai Y, Sakai K, Abe K, Demura H \& Suda T 1996 Major role of $3^{\prime}, 5^{\prime}$-cyclic adenosine monophosphate-dependent protein kinase A pathway in corticotropin-releasing factor gene expression in the rat hypothalamus in vivo. Endocrinology 137 2389-2396.

Kasckow JW, Aguilera G, Mulchahey JJ, Sheriff S \& Herman JP 2003a In vitro regulation of corticotropin-releasing hormone. Life Sciences 73 769-781.

Karalis K, Muglia LJ, Bae D \& Hilderbrand JA 1997 CRH and the immune system. Journal of Neuroimmunology 72 131-136.

Kasckow J, Mulchahey JJ, Aguilera G, Pisarska M, Nikodemova M, Chen HC, Herman JP, Murphy EK, Liu Y, Rizvi TA et al. 2003b Corticotropinreleasing hormone (CRH) expression and protein kinase A mediated $\mathrm{CRH}$ receptor signalling in an immortalized hypothalamic cell line. Journal of Neuroendocrinology 15 521-529.

Komori T, Miyahara S, Yamamoto M, Matsumoto T, Zhang K, Nakagawa M, Nomura S, Motomura E, Shiroyama T \& Okazaki Y 2003 Effects of odorants on the hypothalamic-pituitary-adrenal axis and interleukin-6 (IL-6) and IL-6 receptor mRNA expression in rat hypothalamus after restraint stress. Chemical Senses 28 767-771.

Kozicz T \& Arimura A 2002 Dopamine- and cyclic AMP-regulated phosphoprotein-immunoreactive neurons activated by acute stress are innervated by fiber terminals immunopositive for pituitary adenylate cyclase-activating polypeptide in the extended amygdala in the rat. Regulatory Peptides 109 63-70.

Legradi G, Hannibal J \& Lechan RM 1998 Pituitary adenylate cyclaseactivating polypeptide-nerve terminals densely innervate corticotropinreleasing hormone-neurons in the hypothalamic paraventricular nucleus of the rat. Neuroscience Letters 246 145-148.

Liu Y, Kalintchenko N, Sassone-Corsi P \& Aguilera G 2006 Inhibition of corticotrophin-releasing hormone transcription by inducible cAMP-early repressor in the hypothalamic cell line, 4B. Journal of Neuroendocrinology 18 $42-49$.

Livak KJ \& Schmittgen TD 2001 Analysis of relative gene expression data using real-time quantitative PCR and the $2(-\Delta \Delta C(\mathrm{~T}))$ method. Methods 25 402-408.

Mastorakos G, Weber JS, Magiakou MA, Gunn H \& Chrousos GP 1994 Hypothalamic-pituitary-adrenal axis activation and stimulation of systemic vasopressin secretion by recombinant interleukin-6 in humans: potential implications for the syndrome of inappropriate vasopressin secretion. Journal of Clinical Endocrinology and Metabolism 79 934-939. 
Miyata A, Arimura A, Dahl RR, Minamino N, Uehara A, Jiang L, Culler MD \& Coy DH 1989 Isolation of a novel 38 residue-hypothalamic polypeptide which stimulates adenylate cyclase in pituitary cells. Biochemical and Biophysical Research Communications 164 567-574.

Miyata A, Jiang L, Dahl RD, Kitada C, Kubo K, Fujino M, Minamino N \& Arimura A 1990 Isolation of a neuropeptide corresponding to the $\mathrm{N}$-terminal 27 residues of the pituitary adenylate cyclase activating polypeptide with 38 residues (PACAP38). Biochemical and Biophysical Research Communications 170 643-648.

Mouri T, Itoi K, Takahashi K, Suda T, Murakami O, Yoshinaga K, Andoh N, Ohtani H, Masuda T \& Sasano N 1993 Colocalization of corticotropinreleasing factor and vasopressin in the paraventricular nucleus of the human hypothalamus. Neuroendocrinology 57 34-39.

Nagano K, Toba K, Akishita M, Kozaki K, Eto M, Hashimoto M, Sudoh N, Yoshimizu M \& Ouchi Y 1997 Identification of arginine vasopressin mRNA in rat aortic smooth muscle cells. Biochemical and Biophysical Research Communications 231 831-834.

Navarra P, Tsagarakis S, Faria MS, Rees LH, Besser GM \& Grossman AB 1991 Interleukins- 1 and -6 stimulate the release of corticotropin-releasing hormone-41 from rat hypothalamus in vitro via the eicosanoid cyclooxygenase pathway. Endocrinology 128 37-44.

Neumann H, Schmidt H, Cavalie A, Jenne D \& Wekerle H 1997 Major histocompatibility complex (MHC) class I gene expression in single neurons of the central nervous system: differential regulation by interferon (IFN)-gamma and tumor necrosis factor (TNF)-alpha. Journal of Experimental Medicine 185 305-316.

Nikodemova M, Kasckow J, Liu H, Manganiello V \& Aguilera G 2003 Cyclic adenosine $3^{\prime}, 5^{\prime}$-monophosphate regulation of corticotropin-releasing hormone promoter activity in AtT-20 cells and in a transformed hypothalamic cell line. Endocrinology 144 1292-1300.

Nomura M, Ueta Y, Serino R, Kabashima N, Shibuya I \& Yamashita H 1996 PACAP type I receptor gene expression in the paraventricular and supraoptic nuclei of rats. Neuroreport 8 67-70.

Nomura M, Ueta Y, Serino R, Yamamoto Y, Shibuya I \& Yamashita H 1999 Effects of centrally administered pituitary adenylate cyclase-activating polypeptide on c-fos gene expression and heteronuclear RNA for vasopressin in rat paraventricular and supraoptic nuclei. Neuroendocrinology 69 167-180.

Piggins HD, Stamp JA, Burns J, Rusak B \& Semba K 1996 Distribution of pituitary adenylate cyclase activating polypeptide (PACAP) immunoreactivity in the hypothalamus and extended amygdala of the rat. Journal of Comparative Neurology 376 278-294.

Schimpl A \& Wecker E 1972 Replacement of T-cell function by a T-cell product. Nature: New Biology 237 15-17.

Seasholtz AF, Thompson RC \& Douglass JO 1988 Identification of a cyclic adenosine monophosphate-responsive element in the rat corticotropinreleasing hormone gene. Molecular Endocrinology 2 1311-1319.

Shioda S, Shuto Y, Somogyvari-Vigh A, Legradi G, Onda H, Coy DH, Nakajo S \& Arimura A 1997a Localization and gene expression of the receptor for pituitary adenylate cyclase-activating polypeptide in the rat brain. Neuroscience Research 28 345-354.
Shioda S, Yada T, Nakajo S, Nakaya K, Nakai Y \& Arimura A $1997 b$ Pituitary adenylate cyclase-activating polypeptide (PACAP): a novel regulator of vasopressin-containing neurons. Brain Research 765 81-90.

Silverman MN, Miller AH, Biron CA \& Pearce BD 2004 Characterization of an interleukin-6- and adrenocorticotropin-dependent, immune-to-adrenal pathway during viral infection. Endocrinology 145 3580-3589.

Spengler D, Rupprecht R, Van LP \& Holsboer F 1992 Identification and characterization of a $3^{\prime}, 5^{\prime}$-cyclic adenosine monophosphate-responsive element in the human corticotropin-releasing hormone gene promoter. Molecular Endocrinology 6 1931-1941.

Suda T, Yajima F, Tomori N, Demura H \& Shizume K 1985 In vitro study of immunoreactive corticotropin-releasing factor release from the rat hypothalamus. Life Sciences 37 1499-1505.

Takaki A, Huang QH, Somogyvari-Vigh A \& Arimura A 1994 Immobilization stress may increase plasma interleukin-6 via central and peripheral catecholamines. Neuroimmunomodulation $1335-342$.

Turnbull AV \& Rivier CL 1999 Regulation of the hypothalamic-pituitaryadrenal axis by cytokines: actions and mechanisms of action. Physiological Reviews 79 1-71.

Vallieres L \& Rivest S 1999 Interleukin-6 is a needed proinflammatory cytokine in the prolonged neural activity and transcriptional activation of corticotropin-releasing factor during endotoxemia. Endocrinology 140 3890-3903.

Vandesande F, Dierickx K \& De Mey J 1977 The origin of the vasopressinergic and oxytocinergic fibres of the external region of the median eminence of the rat hypophysis. Cell Tissue Research 180 443-452.

Venihaki M, Dikkes P, Carrigan A \& Karalis KP 2001 Corticotropin-releasing hormone regulates IL-6 expression during inflammation. Journal of Clinical Investigation 108 1159-1166.

Whitnall MH 1993 Regulation of the hypothalamic corticotropinreleasing hormone neurosecretory system. Progress in Neurobiology 40 573-629.

Yoshida M, Iwasaki Y, Asai M, Takayasu S, Taguchi T, Itoi K, Hashimoto K \& Oiso Y 2006 Identification of a functional AP1 element in the rat vasopressin gene promoter. Endocrinology 147 2850-2863.

Zhou D, Kusnecov AW, Shurin MR, DePaoli M \& Rabin BS 1993 Exposure to physical and psychological stressors elevates plasma interleukin 6: relationship to the activation of hypothalamic-pituitary-adrenal axis. Endocrinology 133 2523-2530.

Received in final form 31 July 2007

Accepted 23 August 2007

Made available online as an Accepted Preprint 23 August 2007 